\title{
Poder e análise organizacional: elementos para uma crítica antiutilitarista
}

\author{
Marcos Procópio * \\ Genauto Carvalho de França Filho**
}

\section{Resumo}

Este estudo procura questionar como algumas concepções teóricas sobre o poder, presentes no campo dos estudos organizacionais, podem limitar a apreensão do fenômeno organizacional, devido à inevitável instrumentalização das relações sociais que elas presumem. Essas concepções são especialmente aquelas que atrelam o poder à capacidade estratégica do indivíduo (ou grupo) de realização de objetivos externos, às quais são identificadas neste estudo pelo rótulo de "poder utilitário". Partindo da premissa de que a teoria sobre o poder é um importante recurso para a atividade de pesquisa e reflexão acerca das organizações, este ensaio procura identificar outras concepções teóricas de poder, passíveis de aplicação na investigação organizacional, capazes de complementar aquelas que se baseiam na racionalidade instrumental. A metodologia escolhida se resume a um trabalho de revisão da literatura que envolve outros campos das ciências humanas, além do campo dos estudos organizacionais, como a sociologia, a ciência política e a filosofia. A aplicação dessas concepções "alternativas" sobre o poder na investigação das organizações visa possibilitar uma compreensão mais adequada da vida organizacional.

Palavras-chave.: Poder, Estudos Organizacionais ; Racionalidade.

\begin{abstract}
This paper is concerned about how some theoretical conceptions of power, which are presents within the organizational studies field, especially those which understand power as a strategic capacity of someone (or some group) to achieve external goals, can restrict the organization phenomenon comprehension due to the utilitarian view that it assumes about people relations. Beginning from the supposition that the theory of power is an important tool in organizational analysis activities, the actual paper wills to identify, through a bibliography revision which involves other fields of social knowledge beyond the organizational studies one - such as sociology, political science and philosophy, other theoretical conceptions of power, which can potentially aid that which is based on the utilitarian rationality towards a more complete understanding of the organization life.
\end{abstract}

Key words: Power, Organizational Studies; Racionality.

\section{Introdução}

Este ensaio discute a temática do poder e sua aplicação no âmbito da análise organizacional, de um ponto de vista exclusivamente conceitual. A importância desse tema pode ser avaliada pelo seu papel central na compreensão da organização e de sua dinâmica. Conforme salienta Bertero, "a análise do poder é fascinante, na medida em que é uma perspectiva privilegiada para o aprofundamento e o desdobramento da própria análise organizacional" (1996, p.34). Tal visão é compartilhada por vários outros autores que trabalham com o tema. A seu modo, Stoppino considera que a importância do poder se verifica “(...) por exemplo, na análise das burocracias, e, mais genericamente, na análise das organizações, onde a estrutura hierárquica mais ou menos acentuada e as diversas formas que ela pode assumir colocam, naturalmente, em primeiro plano, o fenômeno do poder" (1999, p.941). Clegg aprofunda ainda mais esse ponto de vista, sugerindo que "qualquer teoria

\footnotetext{
* Professor de Administração na Faculdade de Tecnologia Empresarial (FTE) em Salvador-BA. E-mail: marcos_procopio@ yahoo.com.br.

** Professor Adjunto da Escola de Administração e do Programa de Pós-Graduação em Administração (NPGA) da Universidade Federal da Bahia. Pesquisador do Núcleo de Estudos sobre Poder e Organizações Locais (NEPOL/UFBA). E- mail: genauto@ ufba.br.

Artigo recebido em julho de 2004 e aceito em setembro de 2004.
} 
genericamente aplicável sobre o poder tem que ser também uma teoria de organizações" (1989, p.17); pois, para ele, falar em organização é falar em poder (CLEGG, 1996).

Se a importância da temática do poder parece inquestionável para a análise organizacional, deve-se salientar, por outro lado, a maneira particular como o poder tende a ser interpretado nesse campo de estudos. Conforme sublinham Hardy e Clegg (2001, p.261), apoiando-se em textos referenciais de Max Weber e Robert Dahl sobre o assunto, nos estudos organizacionais, "o poder tem sido visto tipicamente como a habilidade de fazer outros fazerem o que você quer que seja feito, se necessário contra a própria vontade deles (Weber), ou fazê-los fazer alguma coisa que eles não fariam em outra situação (Dahl). Essa definição, aparentemente simples (...) tem sido contestada, emendada, criticada, estendida e repelida ao longo dos anos; mas apesar de tudo, permanece como o ponto de partida para um notavelmente diverso campo de literatura".

Essa tendência a restringir o entendimento da questão do poder no campo dos estudos organizacionais já havia sido assinalada anteriormente. O próprio Clegg (1989) afirmara antes, apoiando-se em Jeffrey Pfeffer, que "a preocupação central da teoria das organizações com o poder vem focando uma concepção restrita de 'política' cuja premissa é o controle de contingências estratégicas ou dependência de recursos" (p.190). Assim visto, o poder é, segundo o autor, “(...) uma 'capacidade' que subentende o controle de recursos” (1989, p.190).

Com o intuito de explicar as razões dessa tendência, Reed (1999) acrescenta que o modelo de poder que se destaca no campo dos estudos organizacionais resulta de uma forte influência dos estudos weberianos sobre poder e burocracia. Apoiando-se em Clegg ${ }^{1}$ e em Dennis Wrong, o autor afirma que "as análises baseadas em Weber enfatizam o caráter relacional do poder como recurso ou capacidade distribuídos de forma diferenciada e que, se empregado com o devido grau de habilidade e tática pelos atores sociais, produz e reproduz relações hierarquicamente estruturadas de autonomia e dependência" (REED, 1999, p.75). Além disso, segundo Clegg (1996, p.50) "o interesse principal das teorias organizacionais de poder é freqüentemente reduzido a uma concepção do político baseada sobre o poder discricionário, sobre os elementos estratégicos ou sobre a dependência em relação a um recurso". A tendência a adotar esse ponto de vista pode ser considerada complementar à perspectiva de Ramos (1989), ao argumentar que “(...) quando a política veio a ser reconhecida como uma dimensão inerente às atividades desenvolvidas nas organizações, a atividade política foi incorporada à elaboração da teoria organizacional; mas mesmo nesse caso, a política era entendida apenas como luta pelo poder, através dos processos de alocação de recompensas" (p.86).

Em resumo, essa concepção de poder, que goza de uma certa hegemonia dentro dos estudos organizacionais devido a sua grande difusão nesse campo (HARDY e CLEGG, 2001; CLEGG, 1989; REED, 1999), pode ser fundamentalmente exemplificada a partir da concepção weberiana de poder, definida como “(...) toda probabilidade de impor a própria vontade numa relação social, mesmo contra resistências (...)” (WEBER, 1994, p.33). A essa concepção dar-se-á, para efeitos metodológicos de desenvolvimento do argumento central deste artigo, o nome de poder utilitário.

A partir dessa discussão, uma constatação importante para conduzir a argumentação consiste em reconhecer que a concepção utilitária de $\operatorname{poder}^{2}$ presume a existência de uma racionalidade instrumental por parte dos atores envolvidos na relação social. Reside precisamente nesse ponto o que parece mais problemático nessa concepção de poder; isto é, o seu caráter redutor. Nesse sentido, argumenta-se aqui que, embora, na maioria dos casos, os fundamentos das práticas de poder encontrem bases utilitárias e estratégicas, não parece adequado afirmar que toda relação de poder se processa, necessariamente, em tais bases. Dito de outro modo, o problema da concepção de "poder utilitário" refere-se a sua pretensa exclusividade de visão. Ele, de fato, parece útil quando aplicado a determinados contextos organizacionais, porém, revela-se limitado em alguns outros. Segundo esse entendimento, o debate sobre o poder deve ser acompanhado de uma discussão sobre a racionalidade. Logo, em contextos organizacionais onde a racionalidade instrumental predomina, o poder tende

\footnotetext{
${ }^{1}$ Segundo Clegg (1996, p.49), “(...) na literatura ortodoxa, a noção de poder organizacional funda-se na mais pura tradição weberiana (...)”.

${ }^{2}$ A exemplo da própria concepção weberiana que - segundo Hardy e Clegg (2001), Clegg (1996) e Reed (1999) - influenciou muitos teóricos que debatem o tema no campo dos estudos organizacionais.
} 
a assumir bases mais utilitárias. O que não necessariamente ocorre em outros contextos, onde a tensão entre distintas racionalidades prevalece ou encontra-se fortemente influenciada por culturas políticas específicas.

Dessa perspectiva, este estudo se interessa, particularmente, pelas restrições que algumas das concepções de poder presentes no campo dos estudos organizacionais - especialmente, aquelas que atrelam o poder à capacidade estratégica do indivíduo, ou grupo, de atingir objetivos externos - podem apresentar como modelos conceituais aplicados à apreensão do fenômeno organizacional.

Assim, este estudo se situa em torno de um duplo objetivo. Em primeiro lugar, pretende dissecar a concepção utilitária de poder, apontando suas restrições, limitações e também suas qualidades, para a análise organizacional. Em segundo lugar, quer discutir - com base em uma revisão da literatura que transcende o campo dos estudos organizacionais - outras concepções de poder, potencialmente aplicáveis à investigação das organizações, capazes de complementar a concepção utilitária rumo a uma mais completa, porém não mais correta, compreensão do fenômeno organizacional.

Alguns postulados básicos sustentam este estudo e merecem ser explicitados. Em primeiro lugar, o poder pode ser visto tanto como um fenômeno social quanto uma teoria ou concepção que representa (ou pretende representar) uma determinada realidade social. Aqui, o poder é estudado primordialmente como teoria, uma vez que o objetivo principal é o enriquecimento do referencial teórico-conceitual utilizado pelo analista organizacional. Em segundo lugar, o poder, como concepção teórica (ou representação teórica da suposta realidade) é tido como um elemento ou ferramenta de pesquisa essencial para a análise organizacional. Isso quer dizer que se supõe ser possível chegar mais perto da compreensão e do entendimento do fenômeno organizacional pela análise do poder, devidamente pautada em uma teoria sobre o mesmo. Em terceiro e último lugar, é importante reconhecer que há uma ligação fundamental entre a teoria do poder e a teoria das organizações (CLEGG, 1989, 1996). Para estabelecer premissas, parte-se da suposição de que as organizações são fundamentalmente compostas por um conjunto de relações sociais que podem, então, ser vistas como relações de poder.

Por ser um estudo dirigido ao "investigador" ou "pesquisador" das organizações, as contribuições aqui pretendidas são mais imediatamente percebidas no próprio campo dos estudos organizacionais. Este artigo parte de uma insatisfação causada pela hegemonia da concepção utilitária de poder na análise sobre as organizações, na qual parte considerável do fenômeno do poder e, por consequiência, do fenômeno organizacional é freqüentemente negligenciada.

Dessa forma, o que justifica este estudo é tanto a possibilidade de se reconhecer as restrições e limitações da concepção utilitária do poder para investigação das organizações, quanto a possibilidade de se estudar as organizações por outras "lentes" teóricas do poder. Em última instância, este ensaio se justifica pela possibilidade de expandir os horizontes da análise das organizações, ao menos no que se refere ao uso das concepções de poder.

Do ponto de vista da sua estrutura, este texto está organizado em quatro partes. Na primeira, é apresentada a concepção de poder predominante na análise organizacional, aqui denominada de "poder utilitário". Em seguida, é abordado o caráter insuficiente dessa concepção para a análise organizacional, através do exame de alguns dos seus limites em termos explicativos. Diante dessa constatação, a terceira parte discute as possibilidades de uma alternativa conceitual a essa forma dominante de entendimento do poder, que se formula em torno do que aqui é chamado de "concepção simbólica do poder". Na conclusão, são confrontadas essas duas concepções. 


\section{0 "poder utilitário"}

Conforme exposto na introdução, existe um modo predominante de entendimento do poder no campo dos estudos organizacionais, que o associa intimamente à capacidade estratégica do indivíduo (ou grupo) de realização de objetivos externos. Essa forma de entendimento do poder, bastante presente na literatura sobre o assunto, será aqui caracterizada como uma concepção utilitária de poder. ${ }^{3}$

Essa concepção, herdeira de uma tradição sociológica particularmente cara a Weber, aparece como fruto de tentativas de se encontrar um pouco mais de precisão no termo, já que a noção de poder é muito empregada e com grande variedade de acepções. Assim, a definição de Boudon e Bourricaud (2000, p.433) parece particularmente ilustrativa dessa concepção de poder: "De modo geral, esse termo remete a três noções conexas que permitem torná-lo um pouco mais preciso. Não há poder sem alocação de recursos, quaisquer que sejam esses recursos. Além disso, é preciso uma certa capacidade para empregar esses recursos. Se confiarmos um computador a um chimpanzé, esse instrumento não aumentará seu poder nem em relação ao homem, que lhe confiou esse recurso, nem em relação a nenhum de seus congêneres. A utilização dos recursos supõe um plano de emprego e uma informação anterior mínima quanto às condições e consequiências desse emprego. Enfim, falar de recursos que podem ser empregados, conforme a capacidade daquele que deles dispõe naturalmente ou que intencionalmente os reuniu em vista dos objetivos que fixou ou que lhe foram propostos ou impostos, significa reconhecer o caráter estratégico do poder e que ele se exerce, eventualmente, não só contra a inércia das coisas, mas contra a resistência das vontades adversas". Para esses autores o poder é, antes de tudo, um processo intencional, e que supõe uma relação assimétrica entre pelo menos dois atores: "Pode-se, como Max Weber, defini-lo como a capacidade de A obter que B faça aquilo que B não faria por si próprio e que é conforme às ordens ou sugestões de A” (p. 433).

Esse ponto de vista também encontra respaldo em Habermas (1990), para quem o conceito weberiano de poder implica a ação utilitária do agente do poder. Conforme ele explica: "Max Weber parte do modelo teleológico de ação: um sujeito individual (ou um grupo, que pode ser considerado como um indivíduo) se propõe um objetivo e escolhe os meios apropriados para realizá-lo. O sucesso da ação consiste em provocar no mundo um estado de coisas que corresponda ao objetivo proposto. Na medida em que tal sucesso depende do comportamento de outro sujeito, deve o ator ter à sua disposição meios que induzam no outro o comportamento desejado" (p.100).

Tal compreensão é também salientada por Clegg (1989), ao lembrar o entendimento do que seja poder em termos de intenções em Weber. Comparando a definição de Weber com a de Russell, para quem poder pode ser definido como a produção de efeitos desejados, Clegg afirma que ambos atrelam o poder ao alcance de resultados esperados: "Assim como Russell, Weber define poder em termos de intenção. Essa intenção, denominada pelo termo 'vontade', é a realização que, mesmo contra a resistência de outros, torna-se um exercício de poder" (1989, p.73). Ainda segundo Clegg (1989, p.73), "outros autores contemporâneos seguem a trilha de precursores como Russell e Weber, na união entre poder e intenção. Para esses autores, uma ação pode ser considerada como uma ação de poder somente se através dela 'A' alcançar algum efeito desejado em face de 'B'. Um bom exemplo contemporâneo seria a modificação que Dennis Wrong faz da concepção de Russell, na qual o primeiro define o poder como 'a capacidade de algumas pessoas de produzir efeitos intencionais e planejados em outros (...)"”.

Por sua vez, Galbraith (1986, p.3), ao interpretar a concepção weberiana de poder, vista por ele próprio como "uma definição próxima à compreensão cotidiana", afirma que há poder quando “(...) alguém ou algum grupo está impondo sua vontade e seu objetivo (ou objetivos) a outros, inclusive aos que se mostram relutantes ou contrários". Segundo esse entendimento, quanto maior a capacidade de impor tal vontade e atingir o correspondente objetivo, maior o poder desse indivíduo ou grupo.

\footnotetext{
${ }^{3}$ Importa salientar que o uso da expressão "poder utilitário" é uma convenção metodologicamente adotada neste estudo para designar um agregado de concepções de poder, presentes na literatura, que apresentam características semelhantes, como será discutido mais adiante. Nenhum dos autores cujas concepções de poder compõem aquilo que aqui é chamado de "poder utilitário" utiliza abertamente essa definição em suas exposições.
} 
Habermas (1990, p.102) destaca que também Talcott Parsons - figura central da tradição sociológica funcionalista e muito conhecido pela interpretação dos estudos de Weber que influenciaram mais diretamente a teoria das organizações (MARSDEN e TOWNLEY, 2001, e SOUZA, 2001) - define o poder como “(...) a capacidade que tem um sistema social de mobilizar recursos para atingir objetivos coletivos". Dessa forma, insiste Habermas, Parsons repete, "ao nível do conceitual sistêmico, a mesma concepção teleológica do poder (poder como potencial para realização de fins) que Max Weber utiliza ao nível da teoria da ação". Esse ponto de vista é reforçado por Lukes (1980, p.23-24), ao considerar que "Parsons busca tratar o poder como mecanismo específico, operado para produzir mudanças na ação de outras unidades, individuais ou coletivas, nos processos de interação social".

Da mesma forma, Faria (2001, p.70) - baseado em uma breve revisão da literatura especializada, a qual inclui a obra de Tragtenberg - afirma que: “(...) poder é a capacidade que possui uma classe social (ou uma de suas frações ou segmentos), uma categoria social ou um grupo (social ou politicamente organizado), de definir e realizar seus interesses objetivos específicos, mesmo contra a resistência ao exercício dessa capacidade e independentemente do nível estrutural em que tal capacidade esteja principalmente fundamentada".

Essa discussão revela a importância de uma racionalidade instrumental (ou por fins), por parte do agente do poder, como aspecto fundamental das referidas concepções. Poder significa, nesse caso, instrumentalizar a relação social (HABERMAS, 1990).

Contudo, nem sempre tal concepção utilitária de poder define-se num contexto de relação direta entre atores. Para alguns autores, a abrangência do "poder utilitário" transcende as relações diretas entre os atores "A" e "B". Pagès e outros (1987) - que insistem sobre as formas "dissimuladas" de poder nas organizações - debatem o poder utilitário a partir de uma perspectiva indireta. Embora, segundo sua análise, ainda seja possível identificar uma "entidade" ou ator interessado na subordinação dos outros, agindo estratégica e intencionalmente de acordo com tal submissão (ator que pode ser a "matriz" ou a "alta cúpula" da empresa multinacional estudada), o poder é exercido indiretamente sobre os subordinados. Para Pagès e outros (1987, p.51), "o exercício do poder não consiste em ordenar, tomar decisões, mas em delimitar o campo, estruturar o espaço no qual são tomadas as decisões".

O ponto máximo de sofisticação dessa concepção dissimulada de poder seria, ainda segundo Pagès e outros (1987), a mediação do próprio desejo dos subordinados. Como reforça Lukes (1980, p.18), “(...) A pode exercer poder sobre B, ao levá-lo a fazer o que não quer, mas também exerce poder sobre ele ao influenciar, moldar ou determinar seus próprios desejos. Com efeito, não é o supremo exercício do poder levar outro, ou outros, a ter os desejos que se queria que tivesse - isto é, assegurar sua obediência, controlando seus pensamentos e desejos?".

\section{Limites do "poder utilitário" para a análise organizacional}

A análise dos limites inerentes a essa concepção utilitária de poder fica mais clara quando são retomadas certas avaliações criticas dessa visão dominante, empreendidas por outros autores.

Uma primeira (e talvez mais evidente) limitação dessa concepção está no fato do poder ser entendido sempre a partir da ação deliberada de sujeitos individuais, vistos como responsáveis exclusivos pelo processo de subordinação em questão. Esse aspecto é salientado por Lukes (1980, p.17), quando retoma a concepção weberiana de poder, entendida como a "(...) probabilidade dos indivíduos realizarem suas vontades, apesar da resistência dos outros (...)". Nesse sentido, embora o receptor do poder não seja necessariamente visto como ator passivo, na concepção utilitária de poder ele interessa apenas à medida que é capaz de resistir e "dificultar" o trabalho do agente do poder. Além disso, segundo essa concepção, há uma necessária separação entre quem tem poder e quem submete-se ao poder. Assim, segundo o modelo utilitário de poder, o processo de subordinação depende totalmente da ação de um ator específico, o agente do poder, necessariamente ativo, consciente, desejoso dessa subordinação e, acima de tudo, hábil, perspicaz e capaz de consegui-la por seu próprio mérito. Trata-se, como observa Lukes (1980), de um exercício, o exercício do poder; onde a questão 
central para entendê-lo passa por identificar quem é (ou foi) deliberadamente responsável pela alteração da conduta do outro (ou outros).

Essa é, sem dúvida, uma grande restrição que a concepção utilitária de poder traz à investigação das organizações. Analisar as relações de poder que compõem a organização através dessa visão implica sempre procurar identificar atores responsáveis por processos de subordinação onde, muitas vezes, não se pode responsabilizar ninguém diretamente. Como bem observa Bourdieu (2001, p.146): "inspirados por um desejo de desmistificação, os pesquisadores freqüentemente tendem a agir como se os agentes sempre tivessem tido como finalidade, no sentido de objetivo, o fim, no sentido de termo, de sua trajetória (...). Transformando o trajeto em projeto (...) atribuem a conduta dos agentes em um campo (...) a uma consciência calculista mais ou menos cínica".

Essa restrição, a que está sujeita a noção de poder utilitário quando aplicada à investigação do fenômeno organizacional, se deve ao fato de que, como observa Lukes (1980), o comportamento dos atores submetidos ao poder não é somente limitado ou direcionado pelo exercício do poder utilitário, tal como praticado pelos agentes do poder. Esse comportamento também é limitado por determinações sociais que, muitas vezes, independem desse exercício, conforme será discutido mais adiante. Dessa forma, procurar saber quem tem mais poder utilitário na organização parece ser um método questionável. Não que esse método seja totalmente restritivo ou ineficaz em todos os aspectos da investigação das organizações; mas, certamente, ele é parcial e precisa ser complementado por outros métodos.

Um segundo limite, derivado da discussão anterior, está relacionado ao aspecto demasiadamente "voluntarista" que a concepção utilitária de poder erroneamente sugere. Ao atribuir importância exclusiva às ações dos agentes do poder no processo de subordinação, a concepção utilitária se esquece de considerar os "determinismos" a que tanto o agente quanto o receptor do poder estão sujeitos na sua relação. Conseqüentemente, a concepção utilitária acaba, de modo equivocado, sugerindo que tais agentes são sempre autônomos ou, em outras palavras, que atuam exclusivamente de forma voluntária ou individualista.

Um terceiro limite pode ser apreendido da leitura crítica feita por Habermas (1980) acerca dessa forma dominante de entendimento do poder. Ele assinala o fato de tal concepção presumir que os atores (agentes do poder) agem e interagem socialmente de forma premeditada e deliberadamente calculada, no sentido da satisfação otimizada dos seus interesses. Agem orientados por um cálculo estratégico que reúne "vontades" e meios disponíveis para satisfazê-las; agem, dessa forma, orientados pela racionalidade instrumental (ou por fins).

Essa ênfase nos interesses ao se definir poder é também sublinhada por Lukes, pois, como tal concepção prevê uma busca consciente e "racional" de satisfação dos fins desejados, no poder (utilitário) "(...) o pressuposto é que os interesses são conscientemente articulados e observáveis" (LUKES, 1980, p.16). Nele há também uma oposição “(...) a qualquer sugestão de que os interesses possam ser desarticulados ou inobserváveis e, acima de tudo, à idéia de que as pessoas possam realmente se equivocar, ou estar desatentas, acerca dos seus próprios interesses" (LUKES, 1980, p.11).

Dessa discussão infere-se que o exercício do poder depende não somente dos desejos e intenções conscientes de um agente de poder (objetivos), mas também da estratégia articulada por tal agente, para tornar efetivos seus desejos e intenções. Depende, ainda, das fontes de poder utilizadas por esse agente, que permitem viabilizar tal exercício. Nesse sentido, um tripé metodológico bastante sedutor para a pesquisa empírica no campo dos estudos organizacionais pode ser, então, deduzido dessa análise. De forma resumida, a figura 1 procura ilustrar os três elementos que ocupam a atenção do investigador organizacional quando este baseia sua pesquisa no modelo conceitual do poder utilitário. Todavia, é importante notar que o agente do poder, elemento que ocupa posição central na ilustração, é um elemento dado segundo o modelo utilitário de poder, cuja racionalidade orientadora de sua ação restringe-se ao cálculo utilitário de conseqüências. 


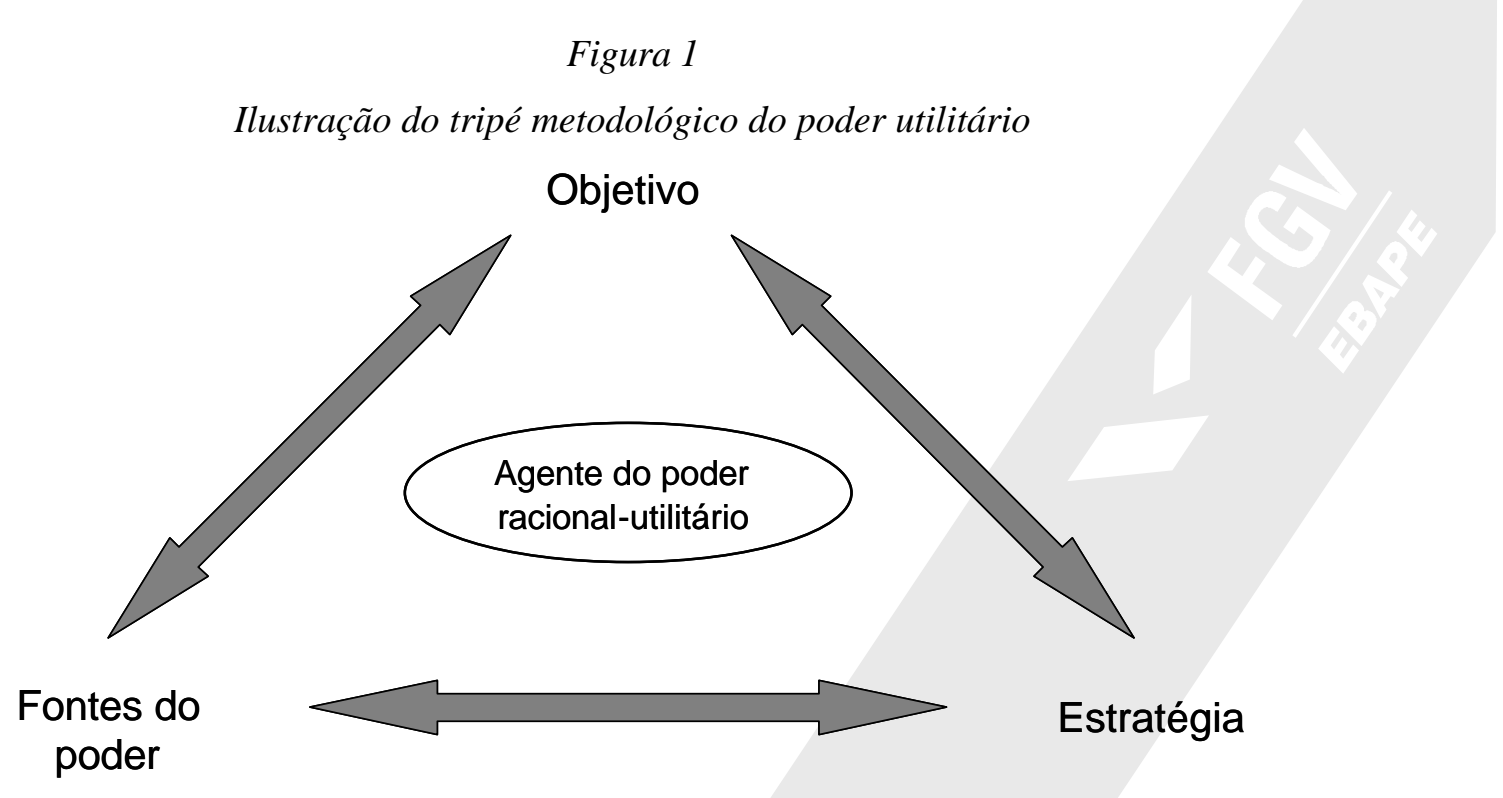

A partir do modelo anteriormente discutido, é perceptível o quanto essa noção de poder é refém de uma explicação utilitária da ação humana. Se essa explicação encontra sua razão e sentido de ser (sobretudo, nos marcos das sociedades contemporâneas que tendem a aprofundar tal dimensão da ação humana com a ascensão do individualismo), ela não permite esgotar a complexidade do agir humano em sociedade (e por conseguinte também nas organizações). Várias são as teorias da ação social que enfatizam o caráter plural dos motivos que influenciam a conduta humana em sociedade. Apenas para tomarmos uma referência clássica, quando Weber (1994, p.15) discute a ação humana em sociedade, seu argumento consiste em mostrar a existência de três outras orientações possíveis para essa ação, além do cálculo utilitário de conseqüências: na racionalidade referente a valores a ação é orientada "pela crença consistente no valor - ético, estético, religioso ou qualquer que seja sua interpretação - absoluto ou inerente a determinado comportamento como tal, independentemente do resultado"; na ação afetiva ou emocional são os "afetos ou estados emocionais atuais" que orientam a ação; e na ação tradicional são os costumes.

Para a análise do poder e, conseqüentemente das organizações, isso significa dizer que, de acordo com Weber (1994), o motivo ou razão de ser das relações sociais construídas pelos atores pode ser encontrado não somente na satisfação do interesse utilitário mas, igualmente, na prática tradicional ou costumeira na qual o ator se insere, na carga e teor dos valores que o ator recebeu no seu processo de socialização e que, diante de uma situação corriqueira, despertam sensos de obrigação; ou mesmo em manifestações emocionais pontuais, que fazem mais sentido para o ator específico que nela se envolve.

O conceito de poder, na sua concepção utilitária - por assumir como orientação da ação a racionalidade instrumental -, se restringe às circunstâncias onde os atores interagem de forma racional-instrumental, tal como prevê o comportamento burocrático ideal descrito por Weber (1994).

Assim, como não é somente através da racionalidade por fins que se relacionam os indivíduos (RAMOS, 1989; GODBOUT, 1998 e 1999; CAILLÉ 1998 e 2002; HABERMAS, 1990; BOURDIEU, 2001; WEBER, 1994), entende-se que o conceito de poder utilitário precisa ser complementado, para uma compreensão mais precisa do fenômeno organizacional, e para que possa ser estendido à análise de outras organizações, além daquelas que operam predominantemente segundo a lógica instrumental, e das que operam em contextos marcados por culturas políticas diferenciadas. 


\section{Alternativas ao poder utilitário para a análise organizacional: a pertinência de uma "concepção simbólica do poder"}

Conforme discutido anteriormente, a concepção utilitária de poder revela-se restritiva para a análise organizacional, na medida em que sugere que a ação consciente e deliberada dos agentes do poder é o único elemento que compõe o processo de subordinação. Essa concepção ignora os aspectos determinantes da ação tanto dos agentes do poder quanto dos receptores, separando-os de forma diacrônica. Portanto, uma concepção de poder capaz de superar essas limitações - e, consequentemente, possibilitar um trabalho de investigação organizacional mais abrangente e profícuo - não pode partir, a priori, de uma perspectiva específica de racionalidade, em função da pluralidade de motivos que podem orientar a conduta humana. ${ }^{4}$

Mais adiante, será abordada a concepção considerada mais pertinente aos objetivos deste texto, e que será aqui denominada de "concepção simbólica do poder". Essa perspectiva tem como ponto de partida a compreensão do sentido peculiar ao contexto em que o poder é analisado. Isso decorre do entendimento de que as relações sociais como relações de significado e sua formulação não partem, a priori, de nenhuma premissa de racionalidade. Esse ponto de vista não refuta, necessariamente, a racionalidade instrumental para compreender as relações de poder.

A análise desenvolvida por Lukes (1980) sobre a significado do poder em Parsons ilustra, ainda que precariamente, a importância da percepção do sentido na relação de poder. Para o autor, "um modo de conceber o poder (ou um modo de definir o conceito de poder), que será útil na análise das relações sociais, precisa implicar uma resposta à questão: 'o que conta como modo significativo?', o que faz A afetar B de maneira significativa?" (LUKES, 1980, p.23). A resposta a essa questão implica uma dupla exigência analítica: a primeira relaciona-se à mudança de ponto de vista na análise do poder, do agente para o receptor. De forma resumida, para compreender o que conta como "influência significativa" em uma relação de poder, deve-se olhar para o influenciado, sua forma de perceber sentido e sua racionalidade (forma de orientar sua ação). Isso porque a percepção do sentido pelo sujeito depende, também, de todo um processo de socialização e compartilhamento de símbolos e experiências de vida que variam, por sua vez, conforme cada contexto social, momento histórico e condições objetivas encontradas no campo social.

Em segundo lugar, a questão proposta por Lukes (1980) implica também uma relativização da premissa individualista ou voluntarista de pesquisa; ou seja, daquela premissa onde os indivíduos agem de forma autônoma e independente uns dos outros (e todos em relação ao contexto social). Isso que dizer que a percepção de sentido não depende somente da parcela de subjetividade intrínseca ao indivíduo, mas também da intersubjetividade determinada ou compartilhada pelo social. Uma forma de entender como a determinação simbólica pode afetar a elaboração da ação dos sujeitos é apresentada por Clegg (1989) que, ao discorrer sobre o estruturalismo de Anthony Giddens, argumenta que "no centro da teoria da estruturação estão pessoas fazendo coisas porque conhecem coisas" (p.142). Levantar o que conta como influência significativa nas relações sociais exige, desse modo, que se considere essa parcela de determinação simbólica, mais ou menos forte que, por sua vez, também explica o poder (LUKES, 1980).

É desse modo que Clegg (1989), ao criticar a concepção de poder de Wrong - vista por ele como uma concepção análoga à weberiana -, argumenta que uma de suas falhas é: “(...) a exclusão de estruturas em que haja a preexistência de significado, sexo e relações de produção; da consideração sobre as ações intencionais que os sujeitos possam executar" (p.75). Esse problema, continua Clegg (1989, p.75), “(...) resulta de uma concepção de poder restrita apenas às questões de agência, em detrimento de qualquer concepção adequada de ligação entre agência e estrutura". Essa concepção de poder de "agência", que pode ser entendida como uma concepção de poder baseada na ação do "agente do poder", está, segundo Clegg (1989), em conflito com uma

\footnotetext{
${ }^{4}$ Alternativas à concepção utilitária de poder foram mapeadas em Procópio (2003).
} 
concepção estrutural. ${ }^{5}$ Embora Clegg (1989) insista nesse ponto, uma concepção de poder simplesmente "estrutural", totalmente embasada na premissa determinista de pesquisa, pode ser tão restritiva à análise organizacional quanto outra totalmente baseada na premissa individualista ou voluntarista.

Parafraseando Clegg (1989, p.12) pode-se dizer que, por trás de qualquer fenômeno de poder utilitário, que ocorre em um contexto social minimamente organizado, existe uma estrutura que prefigura as trocas concretas; aquilo que Peter Bachrach e Morton Baratz chamam de "preconceito do sistema" (LUKES, 1980). Ainda parafraseando Clegg (1989, p.12), a estrutura social predetermina o exercício do poder e, portanto, deve ser entendida como algo que está presente na relação de poder e não como algo externo a ela. Da mesma forma, Stoppino (1999, p.942) observa que “(...) o processo de decisão não tem lugar no vácuo mas num determinado contexto organizativo. Ele parte de instituições, de regras de jogo e de valores que pré-selecionam as propostas admissíveis ao processo de decisão e caracterizam a orientação geral da ação pública". Ainda nesse sentido, Boudon e Bourricaud (2000, p.2-3) afirmam que "a ação de um indivíduo desenvolve-se sempre no interior de um sistema de coerções sociais, definidas com maior ou menor clareza, com maior ou menor transparência para o sujeito, com maior ou menor rigor".

Galbraith (1986), mesmo tendo reforçado a concepção utilitária de poder com sua interpretação "conservadora" da proposta weberiana (conforme mencionado anteriormente), em determinado momento de sua obra Anatomia do poder dá um bom exemplo de como é possível analisar o fenômeno do poder a partir de uma perspectiva menos voluntarista e também menos utilitária. Quando trata do "poder condicionado", a terceira dimensão de poder segundo sua tipologia proposta, ${ }^{6}$ Galbraith $(1986$, p.25) afirma que "enquanto o poder condigno e o compensatório são visíveis e objetivos, o poder condicionado, em contraste, é subjetivo; nem os que o exercem, nem os que se sujeitam a ele estão necessariamente sempre cientes de que ele está sendo exercido".

A submissão no poder condicionado, segundo o autor, “(...) pode ser deliberadamente cultivada - pela persuasão ou pela educação", o que caracteriza o "condicionamento explícito", "ou pode ser ditada pela própria cultura; a submissão é considerada normal, apropriada ou tradicionalmente correta", o que caracteriza o "condicionamento implícito" (GALBRAITH, 1989, p.25-26). Mais adiante, o autor retoma a definição do "poder condicionado" de uma forma bastante clara e elucidativa, ao dizer que “(...) tal poder pode ser explícito, o resultado de uma tentativa direta e clara para conquistar a crença que, por sua vez, reflete os propósitos do indivíduo ou grupo que busca ou exerce o poder. Ou então a crença pode estar implícita na condição social ou cultural; a submissão à autoridade de outros reflete a idéia aceita sobre o que o indivíduo deve fazer" (p.30). O "condicionamento explícito" de que trata Galbraith (1986), ainda pode ser interpretado como uma concepção utilitária de poder. Entretanto, como não se refere a uma relação direta entre "A" e "B", mas sim, à construção deliberada de uma "crença" por "A", que serve para mediar a relação "AB", não pode ser entendido como um modelo de "poder utilitário direto", mas sim como modelo de "poder utilitário indireto".

Uma relação de poder onde um ator procura deliberadamente criar uma superestrutura para "persuasão" ou "educação" de outro - com o intuito de "condicioná-lo" a agir ou pensar de determinada maneira para que, com isso, possa atender a algum interesse -, não deixa de ser utilitária (ao menos para o agente do poder), embora possa não ser direta. Segundo a análise de diversos teoristas críticos das organizações, como Pagès e outros (1987) e Tragtenberg $(1974,1980)$, é justamente esse o papel das políticas e práticas de gestão de recursos humanos nas empresas e, em última análise, das teorias de administração de maneira geral. Gestão da cultura

\footnotetext{
${ }^{5}$ Nesse texto, o termo "agente do poder" é empregado para se referir ao ator social que em dada relação exerce poder sobre outro, de modo utilitário. 0 termo é uma adaptação do que seria "agencia" no texto de Clegg (1989). Segundo Clegg (1989, p.41), o modelo de poder de agência refere-se a "(...) quando um agente faz com que outro faça algo que não faria de outra forma (...)".

${ }^{6}$ Julgou-se não ser necessário um aprofundamento sobre as categorias de poder "condigno" e "compensatório", propostas por Galbraith (1989). De qualquer modo, tanto uma quanto a outra podem ser entendidas como formas utilitárias de poder onde, na primeira, a fonte de poder que permite ao agente do poder exercitá-lo é sua capacidade de punir os subordinados, enquanto que na segunda forma é a capacidade de premiá-los.
} 
organizacional, se é que ela é possível, bem como disseminação de ideologias gerenciais, são também exemplos do "poder condicionado explícito" segundo os críticos. ${ }^{7}$

Porém, a despeito do "condicionamento implícito", a tipologia de Galbraith (1986) permite ir ainda mais longe. Dizer que numa certa relação social não há consciência, por parte dos atores, de que o poder está sendo exercitado, significa tirar de cogitação o utilitarismo, expresso pelo próprio exercício instrumental do poder.

Paralelamente, sobre a questão da consciência e do exercício do poder, Lukes (1980), ao apresentar as contribuições "evolutivas" que Bachrach e Baratz dão à face do poder que aqui se entende como utilitária, afirma que, segundo esses autores, "na extensão em que uma pessoa ou grupo - consciente ou inconscientemente - cria ou reforça barreiras ao arejamento público dos conflitos de política, aquela pessoa ou grupo tem poder" (p.13).

Embora Lukes (1980) tenha concluído sua análise a respeito da contribuição de Bachrach e Baratz afirmando que não houve, efetivamente, grande ruptura com o modelo utilitário, sua observação permite algumas análises muito pertinentes: se interpretada sob a hipótese de que o ator (nesse caso, o agente do poder) "cria ou reforça barreiras de forma intencional", não se torna possível, de fato, romper com a premissa utilitária do poder. Entretanto, uma vez interpretada segundo a hipótese de que o ator "cria ou reforça barreiras de forma inconsciente", pode-se chegar a conclusões muito mais pertinentes pois, uma ação inconsciente, ao menos na sua operacionalização, não pode ser utilitária.

A partir da discussão desenvolvida anteriormente, pode-se notar que o poder existe, em certas relações sociais, não exclusivamente a partir da ação deliberada e condicional do agente do poder. Tal agente, por sua vez, deixa inclusive de ser visto como entidade exclusivamente responsável pelo exercício do poder. Além disso, a própria noção de "exercício" do poder é questionada, bem como as noções de "agente" e "receptor" do poder. Ao mesmo tempo, a percepção de sentido, por parte dos atores sociais, vai tomando a posição de elemento explicativo das suas ações, espaço antigamente ocupado pelo interesse utilitário. ${ }^{8}$ Aqui os atores se comportam da forma como o fazem porque encontram certo sentido nas relações sociais das quais fazem parte. ${ }^{9}$ Esse sentido, por sua vez, pode tanto ser construído a partir de experiências de sociabilização anteriores, cognitivamente interiorizadas, quanto pode ser construído a partir do compartilhamento de normas e

\footnotetext{
${ }^{7}$ Entretanto, como bem alerta Bourdieu (2001, p.44), a partir dessa análise deve-se tomar cuidado para não despertar o “(...) fantasma da conspiração, que comumente ronda o pensamento crítico; a idéia de que uma vontade malévola seria responsável por tudo o que ocorre de melhor e, sobretudo, de pior, no mundo social". Parece claro, pois, que por mais poderoso (no sentido utilitário) que possa ser determinado agente, ou seja, por mais eficiente que este seja na manipulação do contexto social simbólico no qual se encontram seus subordinados, tal manipulação sempre apresenta limites. Bertero (1996) dá um exemplo de como chefes e donos de negócios podem (na perspectiva utilitária) usar seu poder para modelar a cultura organizacional. Entretanto, usando esse mesmo exemplo, seria improvável supor que esses chefes ou donos de negócios poderiam, individualmente, modelar a cultura ou os costumes sociais mais gerais, nos quais a cultura organizacional se inscreve, mesmo porque estes são, em grande parte, disseminados por outras instituições que antecedem à empresa no processo de socialização dos indivíduos, como a família e a escola (MOTTA, 1986). Seja como for, mesmo tratando-se especificamente da cultura organizacional, há controvérsias no âmbito da teoria das organizações sobre o fato desta ser ou não ser "gerenciável", como observa Pettigrew (1996).

${ }^{8}$ Embora Galbraith (1986) não tenha desenvolvido sua análise acerca do "poder condicionado implícito" na direção do detalhamento de como os atores "conformam- se" às normas e prescrições sociais, essa concepção de poder não pode ser tachada, a priori, como uma concepção totalmente determinista; e isso se deve pelo menos a dois motivos. Em primeiro lugar, Galbraith (1986) se preocupa explicitamente com as determinações simbólicas da ação dos atores e não faz menção sobre as determinações objetivas. As determinações simbólicas que constrangem e direcionam a ação diferem-se das objetivas justamente por passarem pela subjetividade do ator que age. Em outras palavras, elas nunca podem ser absolutas e sempre dependem de algum nível de "interpretação". Em segundo lugar, uma concepção de poder totalmente determinista (na acepção mecânica e objetiva) seria incompatível com grande parte dos exemplos analisados por Galbraith (1986), quando o autor trata sobre o "poder condicionado implícito", uma vez que sua pesquisa encontra-se bem próxima de uma análise prática do poder em diversos contextos sociais.

${ }^{9}$ É importante destacar que a análise do poder hora desenvolvida, através da concepção do "poder condicionado implícito" de Galbraith (1986), não é realizada pelo autor em seu texto. A inserção da noção de sentido na análise do poder, partindo de tal concepção, bem como 0 cruzamento dessa concepção com outras teorias que tratam do tema, são recursos aqui empregados para um melhor esclarecimento do conceito de poder simbólico.
} 
significados sociais que, em última instância, independem do exercício específico do poder por parte de um agente qualquer. Em suma, a ação do ator é guiada pelo sentido por ele percebido. ${ }^{10}$

\section{Conclusões: "poder utilitário" e "poder simbólico" - algumas comparações}

A relação teórica entre o "poder utilitário" e o "poder simbólico", tais como metodologicamente definidos neste estudo, não é uma relação de contestação direta. Na verdade, como aqui se tentou demonstrar, o poder simbólico não nega e nem pretende negar o poder utilitário. Além disso, muitas formas de poder utilitário são também simbólicas. O poder simbólico, por trazer a discussão sobre a dominação para um nível de análise anterior ao poder utilitário, acaba por envolvê-lo e não o nega diretamente. Se o poder utilitário "peca" por assumir como utilitárias as relações sociais que não necessariamente o são, o poder simbólico evita partir de uma premissa racional predefinida e vai procurar respostas para as situações de dominação no sentido percebido pelos atores. Todavia, isso não significa, como já argumentado, que esse sentido não possa ser o utilitário, a depender do contexto social e organizacional em questão.

É justamente por levar a análise sobre o poder a um nível anterior ao da racionalidade meramente instrumental que o modelo simbólico de poder se apresenta como um modelo "mais completo" - mas não "totalmente completo" e nem "mais correto" - para a investigação do fenômeno organizacional, em relação ao modelo utilitário de poder. Contudo, pelo mesmo motivo, ou seja, por exigir, no trabalho de pesquisa empírica, uma atenção e um esforço maior de compreensão dos motivos e razões que estão por trás da ação social, em vez de simplesmente partir do pressuposto de que todos os atores agem de forma racional-instrumental, o modelo de poder simbólico tem uma desvantagem, pois apresenta-se como um modelo mais trabalhoso para a pesquisa em relação ao modelo utilitário. A seguir, são apresentados de forma resumida dois aspectos comparativos entre essas duas concepções de poder, considerados como mais relevantes no plano de uma análise organizacional.

\section{Exercício do poder versus existência do poder}

A primeira importante diferença entre a concepção simbólica e a concepção utilitária do poder está no papel dos atores envolvidos no processo de subordinação. Enquanto a concepção utilitária reforça a importância da ação do agente do poder, a concepção simbólica a relativiza, dando importância à percepção do sentido da relação para todos os atores envolvidos, quer estejam na posição de dominadores ou na de dominados. No poder simbólico todos os atores envolvidos na relação agem para que o poder seja consumado, já que a percepção de sentido já é uma ação por si mesma, por mais que não seja consciente para o ator.

Em suma, enquanto o modelo de poder utilitário se preocupa com o "exercício" do poder, com agentes, receptores e fontes de poder, o modelo simbólico preocupa-se, de forma mais abrangente, com a "existência" do poder. Porém, o faz sem negar a existência do exercício deliberado. Falar em agentes, receptores e fontes de poder torna-se mais impreciso quando se estuda o fenômeno através do modelo simbólico. De acordo com essa concepção, o poder pode ser verificado nas relações sociais através da compreensão dos motivos e razões que levam os atores a agirem da forma que agem, independentemente de estarem sendo intencionalmente direcionados para agirem assim. Isso porque os sujeitos sempre carregam consigo, na formulação de suas ações e/ou julgamentos dentro das organizações, certas disposições, cognitivamente adquiridas, independentemente destas terem (ou não) sido construídas ou modeladas deliberada e condicionalmente por outros agentes utilitariamente interessados.

\footnotetext{
${ }^{10}$ Em um nível de análise menos sofisticado, os exemplos desenvolvidos por Galbraith (1986), bem como o próprio conceito de "poder condicionado implícito" desse autor, remetem ao "poder existente" em detrimento do "poder exercido", tais como discutidos por Clegg (1989) quando este se refere ao estudo de Dahl.
} 


\section{Sobre 0 controle}

A segunda importante diferença entre a concepção simbólica e a concepção utilitária do poder diz respeito ao aspecto do controle organizacional. Marsden e Townley (2001) definem o controle como uma situação onde "A consegue que $B$ faça alguma coisa que ele/ela não desejaria ou não deveria fazer; em outras palavras, "controla"” (p.47).

Tomando-se essa simples definição como base, seria possível então questionar: ora, se no modelo de poder simbólico não há necessariamente receptor do poder (B) ou agente do poder (A) utilitariamente interessado na dominação; se no modelo de poder simbólico nem todas as relações sociais são deliberadamente desenvolvidas com vistas a um objetivo ou condição futura almejada por determinado agente; se no modelo de poder simbólico não há necessariamente consciência por parte dos atores de que existe poder na relação em que eles se encontram; ou ainda indagar se não existe controle nesse modelo teórico de poder.

Certamente, a resposta é negativa e seu aprofundamento exige uma relativização da concepção de controle anteriormente apresentada. Da mesma forma exige o reconhecimento de que o controle social pode existir em outros níveis além daquele onde se encontra, isto é, nas mãos de atores ou instituições individuais que o "desejam" e o "cultivam" com segundas intenções. Partindo de um entendimento mais amplo do controle (visto como tudo aquilo que, presente em uma relação social, dá a ela previsibilidade ou regularidade), é possível perceber que o controle "personificado", ou seja, aquele exercido de forma consciente e deliberada por um indivíduo ou instituição sobre outros, é apenas um dentre outros modelos possíveis.

Diferentemente do que se verificou no modelo de poder utilitário, no modelo de poder simbólico o "controle" se encontra em outro nível das relações sociais, não simplesmente como um empreendimento de uma ator (A) "qualquer", que procura deliberadamente satisfazer um interesse que depende desse controle, mas também como uma conformação social, até certo ponto interiorizada nos sujeitos e operada por eles próprios

Dentro das organizações burocratizadas, grande parte do controle sobre o trabalho de seus membros é exercido através da fórmula utilitária de poder, mais especificamente, através do poder utilitário indireto (PAGÈS et al., 1987). Entretanto, nem mesmo nesses contextos sociais pode-se dizer que o controle concernente ao exercício do poder utilitário é o único e exclusivamente responsável pela previsibilidade das relações lá existentes. Como discutido antes, parte da previsibilidade presente neste e em outros tipos de organização (menos burocratizadas) advém do fato de que seus membros já carregam consigo, muito antes de entrarem em tais organizações, modelos de ação e relacionamento já interiorizados, capazes (até certos limites) de modelar seu comportamento. Com efeito, "é a identificação de seus membros com um modelo comum que assegura a unidade simbólica de instituições como o Exército e a Igreja" (BOUDON e BOURRICAUD, 2000, p.102).

Por exemplo, em uma sala de aula, a relação de poder entre professor e alunos se dá tanto de forma utilitária quanto simbólica. O professor, agindo de forma consciente e planejada, recorre a uma série de meios para transmitir o conhecimento aos alunos (seu objetivo deliberado) e, assim, exercita o poder utilitário, tanto direta quanto indiretamente (na medida em que procura criar "condições" de aprendizagem). Entretanto o professor, por si só, não é o único responsável pela "eficiência" final do processo de aprendizagem, admitindo-se que essa eficiência se mede pela obtenção do objetivo pretendido pelo professor, ou seja, transmissão do conhecimento aos alunos. Quanto aos alunos, estes trazem para a sua relação com o professor todo um modelo de comportamento - mais ou menos previsível, que foi desenvolvido durante seu processo de socialização e educação -, pelo qual, querendo ou não, eles estão mais ou menos predispostos a se submeter ao professor. Dito de outro modo, este, devido à posição estrutural simbólica que ocupa no contexto da sala de aula, já goza, independentemente de querer ou não, de uma predisposição dos alunos em ouvi-lo e obedecê-lo. Por sua vez, tal predisposição é paulatinamente incutida nos alunos durante todo seu processo de socialização, inclusive fora do ambiente escolar, quando lhes é ensinada a importância do respeito ao pai, na família, do respeito aos mais velhos, na comunidade, e do respeito ao professor, na escola. Conseqüientemente, são também condicionados a respeitar a hierarquia, na empresa, bem como respeitar o direito de propriedade em relação ao capital. 
Assim, parte do controle social na relação entre professor e aluno, bem como entre chefe e empregado, e entre pais e filhos, ocorre num nível simbólico e não utilitário da relação, embora outra parte se dê efetivamente neste último nível, ainda que ambos "controles" possam freqüentemente coexistir.

Em suma, a concepção utilitária de poder remete o controle social ao nível do agente do poder. Na dimensão direta do poder utilitário esse controle é diretamente exercido por "A" sobre "B", enquanto que, na dimensão indireta, é exercido por "A" através da mediação da relação "AB" ou através da manipulação do contexto simbólico ou objetivo onde se verifica a relação entre "A" e "B". Entretanto, na concepção simbólica do poder o controle social não é necessariamente "empreendido" pelo agente do poder, nem direta nem indiretamente, uma vez que os atores sociais não possuem, necessariamente, intenções utilitárias, objetivos específicos, ou mesmo consciência de que tal controle existe. Na concepção simbólica do poder, o controle social se concentra no nível "macro" social ou estrutural.

\section{Referências bibliográficas}

BERTERO, C. O. Cultura organizacional e instrumentalização do poder. In: FLEURY, M. T. L.; FISCHER, R.. (Coord.). Cultura e poder nas organizações. 2.ed. São Paulo: Atlas, 1996. p.29-44.

BOUDON, R.; BOURRICAUD, F. Dicionário crítico de sociologia. 2.ed. São Paulo: Ática, 2000.

BOURDIEU, P. Razões práticas. 3.ed. Campinas: Papirus, 2001.

CAILLÉ, A. Nem holismo, nem individualismo metodológico: Marcel Mauss e o paradigma da dádiva. Revista Brasileira de Ciências Sociais, v.13, n.38, p.53-75, out. 1998.

Antropologia do dom: o terceiro paradigma. Petrópolis: Vozes, 2002.

CLEGG, S. Frameworks of power. Londres: Sage, 1989.

Poder, linguagem e ação nas organizações. Tradução. Ofélia de Lanna Sette Tôrres. In: CHANLAT, J.-F. (Coord.). 0 indivíduo na organização: dimensões esquecidas. 3.ed. São Paulo: Atlas, 1996. v.1, p.47-63.

FARIA, J. H. Poder e participação: a delinqüência acadêmica na interpretação tragtenberguiana. RAE - Revista de Administração de Empresas, São Paulo, v.41, n.3, p.70-76, jul./set. 2001.

FRANÇA FILHO, G. C. Para um olhar epistemológico da administração: problematizando o seu objeto. In: SOUZA SANTOS, R. (Org.). Discussões metodológicas para a reafirmação da administração como campo do conhecimento. São Paulo: Hucitec, 2004. (Edições Mandacaru).

GALBRAITH, J. K. Anatomia do poder. 3.ed. São Paulo: Pioneira, 1986.

GODBOUT, J. T. Introdução à dádiva. Revista Brasileira de Ciências Sociais, v.13, n.38, p.39-52, out. 1998.

O espírito da dádiva. Rio de Janeiro: Editora FGV, 1999.

HABERMAS, J. 0 conceito de poder em Hannah Arendt. In: FREITAG, B.; ROUANET, S. P. (Coord.); FERNANDES, F. (Org.). Habermas. São Paulo: Ática, 1990. p.100-118. (Coleção Grandes Cientistas Sociais - sociologia).

HARDY, C.; CLEGG, S. Alguns ousam chamá-lo de poder. Tradução: Vitarque Lucas Coelho, Tomaz Assmar Santos. Revisão: Tânia Fischer. In: CLEGG, S.; HARDY, C.; NORD, W. (Org.). Handbook de Estudos Organizacionais: reflexões e novas direções. São Paulo: Atlas, 2001. v. 2, p. 260-289.

LUKES, S. 0 poder: uma visão radical. Brasília: UnB, 1980.

MARSDEN, R.; TOWNLEY, B. Introdução: a coruja de Minerva - reflexões sobre a teoria na prática. Tradução: Ângela Denise da Cunha Lemos. In: CLEGG, S.; HARDY, C.; NORD, W. (Org.). Handbook de Estudos Organizacionais: reflexões e novas direções. São Paulo: Atlas, 2001. v. 2, p. 31-56.

M OTTA, F. C. P. Organização e poder: empresa, Estado e escola. São Paulo: Atlas, 1986.

PAGÈS, M. et al. 0 poder das organizações. São Paulo: Atlas, 1987.

PETTIGREW, A. M. A cultura das organizações é administrável? In: FLEURY, M. T. L.; FISCHER, R. M. (Coord.). Cultura e poder nas organizações. 2.ed. São Paulo: Atlas, 1996.

p. $145-153$.

PROCÓPIO, M. L. Poder e análise organizacional: rompendo os limites da racionalidade instrumental. Dissertação (M estrado) - NPGA/UFBA, Salvador. 2003. 
RAM OS, A. G. A nova ciência das organizações: uma reconceituação da riqueza das nações. 2.ed. Rio de Janeiro: FGV, 1989.

REED, M. Teorização organizacional: um campo historicamente contestado. Tradução: Jader Cristino de Souza, Marcos Cerqueira Lima. In: CLEGG, S.; HARDY, C.; NORD, W. (Org.). Handbook de Estudos Organizacionais: reflexões e novas direções. São Paulo: Atlas, 1999. v. 1, p.61-98.

SERVA, M. 0 paradigma da complexidade e a análise organizacional. RAE - Revista de Administração de Empresas, São Paulo, v.32, n.2, p.26-35, abr./jun. 1992.

SOUZA, R. S. 0 funcionalismo sistêmico nas teorias social e organizacional: evolução e crítica. REAd - Revista Eletrônica de Administração, Porto Alegre, v.7, n.1, mar. 2001. Disponível em: <http://read.adm.ufrgs.br/read19/artigo/artigo1.htm>. Acesso em: 18 jul. 2002.

STOPPINO, M. Poder. In: BOBBIO, N.; MATTEUCCI, N.; PASQUINO, G. Dicionário de Política. 12.ed. Braślia: UnB, 1999. v.2, p.933-943.

TRAGTENBERG, M. Administração, poder e ideologia. São Paulo: Moraes, 1980.

Burocracia e ideologia. São Paulo: Ática, 1974.

WEBER, M. Economia e sociedade. 3.ed. Brasília: UnB, 1994. v.1. 